\title{
The Training Implementation in Improving The Pedagogical Competence of Teachers for A Quality Education in Madrasas
}

\author{
Agustina $^{1}$, I Abdulhak ${ }^{2}$, Rusman $^{2}$ \\ ${ }^{1}$ Balai Diklat Keagamaan Palembang, Palembang, Indonesia \\ ${ }^{2}$ Department of Informal Education, Universitas Pendidikan Indonesia, Bandung, Indonesia \\ ${ }^{1}$ agustinadjihadi.ad@gmail.com
}

\begin{abstract}
The quality of education at madrasas is considered low due to its percentage of students' graduation and its number of students who continue their study to higher education. The most influencing factor that contribute to this are the low quality teachers regarding to the qualification and competence, especially in pedagogical competence. The government's efforts to improve the madrasas teachers' pedagogical competence is through the trainings for teachers. Related to this, this research was aimed to evaluating the implementation of trainings for teachers and how this trainings affected the teachers' pedagogical competence, by a case study by using the questionnaire, the test and observation on the teachers' pedagogical performance towards 104 teachers coming from four provinces in Indonesia. The results of the research showed that the implementation of the training for teachers were good except the indicator of curriculum and syllabus; the teachers' pedagogical competence after the training was good except the indicator of the developing students' potential; and there was increasing in the teachers' competence after the training as shown in the result of $\mathrm{T}$ test. It is strongly reccomended to the teacher training curriculum developer to improve the quality of curriculum and syllabus and adapt them with the needs of the teachers and emphazise on the development of students'.
\end{abstract}

Keywords: Pedagogic, Teachers, Madrasas

\section{INTRODUCTION}

The Sustainable Development Goals (SDGs) were created by leaders from 193 countries of the world in the year 2015, covering 17 goals for better future. The United Nations Development Programme (UNDP) is one of the leading organizations working to fulfil the SDGs by the year 2030. One of the important goals is to ensure inclusive and equitable quality education and promote lifelong opportunities for all, focuses on Education, based on the targets set by the Education 2030 Incheon Declaration and Framework for Action. The quality education targets by 2030 are to ensure that all girls and boys complete free, equitable and quality primary and secondary education leading to relevant and effective learning outcomes; to ensure all girls and boys have access to quality early childhood development; to ensure equal access for all women and men to affordable and quality technical, vocational and tertiary education, including university; to substantially increase the number of youth and 
adults who have relevant skills, including technical and vocational skills, for employment, decent jobs and entrepreneurship; to eliminate gender disparities in education and ensure equal access to all levels of education and vocational training, including persons with disabilities, indigenous peoples and children in vulnerable situations; to ensure that all youth and a substantial proportion of adults, both men and women, achieve literacy and numeracy; to ensure that all learners acquire the knowledge and skills needed to promote sustainable development, including, among others, through education for sustainable development and sustainable lifestyles, human rights, gender equality, promotion of a culture of peace and non-violence, global citizenship and appreciation of cultural diversity and of culture's contribution to sustainable development [1]. The contribution of Education for All (EFA) was considered to be a vehicle for the sustainable development of our world. Achieving inclusive and quality education for all reaffirms the belief that education is one of the most powerful and proven vehicles for sustainable development.

In Indonesia, the quality education should be taken into account in the context of madrasas. Madrasas have been rapidly grown into the modern Islamic education institutions in many countries with the increasing numbers of the students by years. However, the quality of education at madrasas is often considered not as good as its improving quantity, including in Indonesia as the country with the largest moslem population. Being compared to the general schools, the quality of madrasas is still so low that the government have ever decided to unite the madrasas into general schools [2].

Some indicators showing this low quality of madrasas were the findings of quality research of madrasas by AusAid in 2010 which investigated 50 madrasas tsanawiyah in the West Indonesia, 50 madrasas tsanawiyah in Java Island, and 50 madrasas tsanawiyah in East Indonesia [3]. The result showed that the madrasas students' performance on Math, Science and English were much lower than international average scores based on the items taken from internatonal assessment like Programme for International Student Assessment (PISA) and Trends in International Mathematics and Science Studies (TIMSS). In addition, the data from Islamic Education General Directory at Ministry of Religious Affairs showed that the result of madrasas students' examination was lower than the nonmadrasas schools especially in the Senior High School level. The data showed that since the national examination in 2007 till 2010 the scores of madrasas aliya students were always lower than general senior high schools [4].

There were many factors influencing this low quality in madrasas, but the factor that was mostly taken into notice by the experts was the teacher factor, in terms of the qualification and competence. The school factor considered to have relations with the students' achievement was teachers' and headmaster's qualification and profesionalism. The research showed that generally madrasas with high quality teachers performed better achievement than other schools [4].

It was mentioned in the national target of SDGs in Indonesia is to subtantially improve the high quality teachers by having national target to improve the academic qualification for all teachers (at least bachelor degree) and to improve the teachers' competence in subject matter and pedagogical knowledge and to improve the teachers' productivity [4]. In fact in madrasas education, not all teachers at madrasas got bachelor degree. The data from Ausaid in 2010 showed that $65.6 \%$ of all teachers' qualification was under Bachelor [5]. In the data of EMIS at Ministry of Religious Affair, there was $47 \%$ teachers of madrasa were in the category "underqualified" [6], and the number of teachers who pass the Teachers Competence Assesment were in the category "low".

Due to this matter, improving madrasas' teachers quality has been a strategical priority for the government, and the effort was done through the education and training for teachers. Training for teachers will always be strongly needed because it will affect the quality of the students' learning, just like Brendefur said, “Teachers' profesional development affects the teaching they do in the class and will be able to increase the quality of students' learning" [7]. Murtazaasserted as well that there is no factor having impact to the students' learning greater than teachers' profesional development [8]. 
Considering the urgency of teaching training for developing the competence of the teachers for quality education in madrasas. it becomes very crucial to evaluate whether or not the training program is done effectively and attains the purpose of the program well. This evaluation is the key factor to improve and maintain the quality of training implemementation in the future. Based on that rationale, the research on the implementation of teacher training was done in the training institute of religious affairs in Palembang covering the teachers from four provinces in Indonesia; South Sumatera, Lampung, Bengkulu and Bangka Belitung Archipelago.

Based on that background of the problems, the problem to investigate on this research was, "How was the implementation of the training for teachers of madrasas to improve the pedagogical competence at the training institute of religious affairs in Palembang?". This problem was formulated into these research questions; a) How was the implementation of the training of the teachers at the training institute of religious affairs in Palembang?, and b) was there any significant improvement on the teachers' pedagogical competence after the training?

Generally, this research was aimed to evaluate the implementation of the training program for teachers of madrasas to improve their pedagogical competence. Spesifically, it was purposed to investigate the implementation of the training for teachers, and to analyze the result of the implementation toward the teachers' pedagogical competence. Program evaluation is a systematic method for collecting, analyzing, and making use of the obtained information to answer the basic questions about a program [9]. Training evaluation in specific is a collection of descriptive and judgmental information required to take an effective decision related to selecting, adopting, evaluating, and modifying the learning activities in the training [10].

\section{LITERATURE REVIEW}

This design of this research was evaluative descriptive research by using a case study. In collecting and analyzing the data, mixed quantitative qualitative method was used, that was a good design to draw the comprehensive conclusion [11]. The focus of this research was evaluative research on the madrasas teachers by using CIPP evaluation model (context, input, process, dan product) but in this study the dimensions were only focused on two kind of evaluation, that were process and product evaluation. Evaluating the two kinds of dimensions did not make this research draw less effective and contributive finding for answering the problems of the research.

The subject of the research were the participants of the Teacher Training at three batches in 2017, they were Training of Integrative Thematic for Madrassas Ibtidaiyah, Training of Instructional Materials, the Training of Instructional Methodology Development with the amount of 104 participants coming from four provinces in Indonesia, they were South Sumatera, Lampung, Bengkulu and Bangka Belitung Archipelago. The data collected for this research was obtained distributing the questionnaires to measure the implementation of the training, the written pre and post test on pedagogical knowledge and the performance assesment through observation to measure the teachers' pedagogical competence. The data then was analyzed by using mixed methodquantitatively and qualitatively by using scoring, tabulation, data description in percentage, and statistical analysis by a T Test.

\section{RESULT AND DISCUSSION}

\subsection{Literature Review}

There were many models can be used to evaluate a training program, for instance the Kirkpatrick model, CIRO, Phillip, Countenance Stake, and CIPP model.The last model sees that the importance aim of evaluating is not to prove but to correct and improve. In this model, education system is categorizes into four dimensions; they are context, input, process, dan product. Context evaluation is to analyze the aim formulation, input evaluation is to evaluate the content of the program, process evaluation is to evaluate the implementation of 
lesson plan that has been developed, and product evaluation is to evalute the learning result of the program [12].

Pedagogical competence is described in the Regulation of Ministry of National Education No.16year 2007 as, a) to have mastery on the students' characteristics, the learning theories and the learning principles, to develop the curriculum related to the subjects and fields, to apply the educative teaching, to make use of Information and Communication and Technology, to facilitate the development of students' potential, to communicate effectively, to assess and evaluate the learning, to make use of the result of evaluation and assessment for better learning, to do reflective treatment to improve the quality of learning [13].

\subsection{Data Analysis Result}

\subsubsection{The implementation of the training program for teachers of madrasas}

There were two parts of questionnaire used, they were the implementation of the training by the committee and the implementation of the training by the trainer. The result figure was shown below.

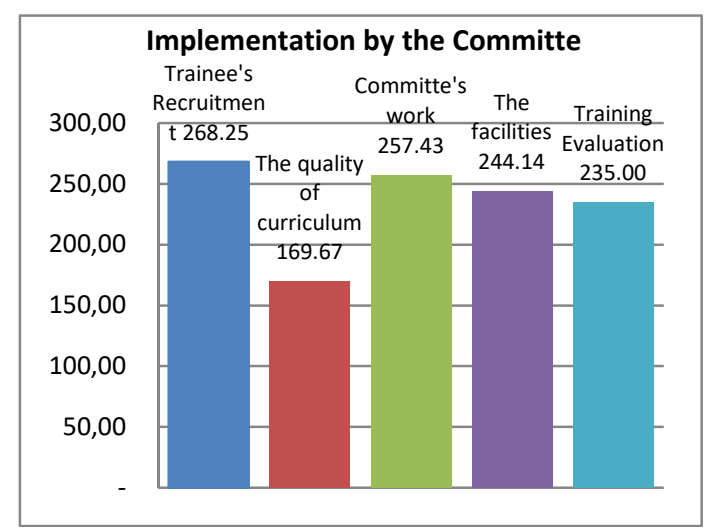

Figure 1. The Analysis of the Implementation of the Training by the Committee.

As shown in the figure 1, this part consisted of some aspects; the aspect of the trainee's recruitment, the committee's work, and facilities were in very good category; the training evaluation was in good category, and the quality of training curriculum and syllaby were in not good category. If we see each indicator on this part, we got one indicator got the least good score, that was the quality of curriculum and syllabus of the training. This indicator itself covered three sub-indicator, they were the distribution of the curriculum and syllabus, the relevance, and the significance. The analysis noted that the last two sub indicators got "less good" scores. However, further analysis noted that the average scores for this part was 268.25 , which was converted to percentage into $75.29 \%$ and that was in "good" category.

The second part of the questionnaire was the implementation done by the trainers, the result was shown in the figure 2 below. 


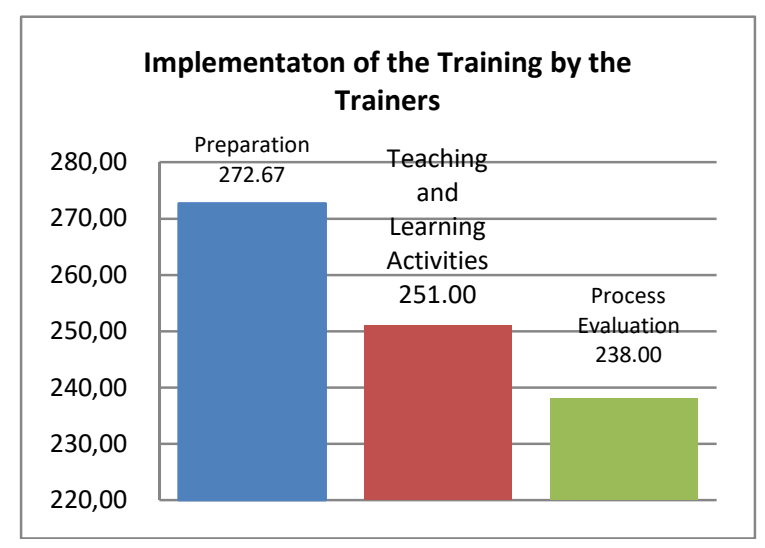

Figure 2.The Implementation of The Teachers' Training By The Trainers

As shown in figure 2, there were three aspects on this part; the aspect of preparation and the aspect of teaching and learning activities got Very Good category and the aspect of training evaluation got "Good" Category. The further data analysis noted that the average scores for this part was 254 , which was converted to the percentage that was $81 \%$, and this was in Very Good category.

Based on these two parts of evaluation, it was shown that the the implementation of the training by the committee was good, and by the trainers was very good. The total average score for these two parts was 245 , which was converted into $76 \%$ and was in the "very good" category.

\subsubsection{The Improvement of the Pedagogical Competence of Madrasas' Teachers}

The latter analysis was on the teachers' pedagogical competence after the training and for this analysis there were two techniques used; the test and observation. The result from the pre and post-test were analyzed by using the $\mathrm{T}$ Test and here was the data.

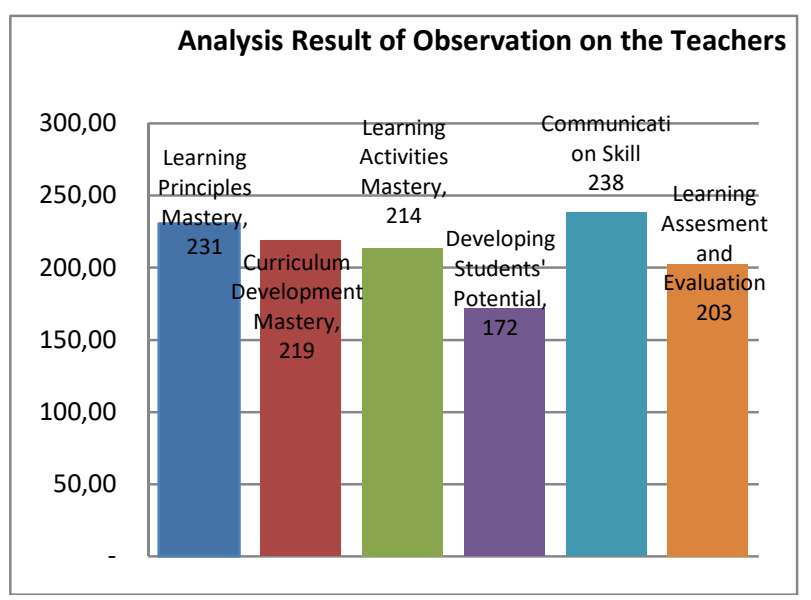

Figure 3. The Analysis of Observation on the Teachers' Pedagogical Competence.

Based on the result of observation above, it can be inferred that the five indicators got good score but one indicator got less good score, that was developing students' potential. The total percentage for all indicators was $68 \%$, that was in good category.

The second part of analysis on the teachers' pedagogical competence was the analysis of the significant difference on the result of the written test on the pedagogical competence before and after the training. This analysis was used to answer this hyphotesis: 
H0: There was no significant difference between the result of the pre-test and post of the teachers on the pedagogical competence

H1: There was a significant difference between the result of the pre-test and post of the teachers on the pedagogical competence

Ho would be accepted if the t-obtained was lower or the same as the t-table with the probability value higher than 0,05 . Meanwhile, H1 woud be accepted if t-obtained is higher or the same as $t$ tablewith theprobability valuelower than 0.05 . The result of the $T$ Test analysis using SPSS 21.00 was shown below.

Table 2. The Result of T Test on the Teachers' Pre and Post Test.

\begin{tabular}{ccccc}
\hline Variable & Average & $\begin{array}{c}\text { Average } \\
\text { Difference }\end{array}$ & $\begin{array}{c}\text { The } \\
\text { value } \\
\text { of T }\end{array}$ & Sig.Level \\
\hline $\begin{array}{c}\text { Pre Test } \\
\text { Post Test }\end{array}$ & 31.83 & -50.929 & $\begin{array}{c}- \\
36.856\end{array}$ & .000 \\
\hline
\end{tabular}

From the table above, it was inferred that the mean of pre-test was 31,827 , and the mean of the post test was 82,756, with the value of $\mathrm{T}-36.856$ and the significant level .000 . Since the value of $\mathrm{t}$ was lower than the $\mathrm{T}$ table $-1,98$, with the probability value .000 that was lower that 0.05 , the null hypotheses was rejected. It means that there were significant different on the pedagogical competence of the teachers after the training as shown in the test.

\subsection{Discussion}

The implementation of the training program by the committee was in good category and the implementation by the trainer was in very good category. It was caused by some factors; they were the appropriate purpose, the relevant method of teaching, the competent trainers, and comfortable environment. It is relevant with what Kant et.al said that many factors which affects training effectiveness. They mentioned some like motivation, attitude, emotional intelligence, support from management and peers, training style and training environment, open-mindedness of trainer, job related factors, self efficacy and basic ability etc [14].

Based on the result of the research, the pedagogical competence of madrasas' teachers was improving. However, the score of the teachers' concern on the students' potentials was not good. According to Hamzah, developing the students' potential is one of the most important things in pedagogical competence. He mentioned that teachers should be not only become the information delivery but also the facilitator, motivator, and guide for the students to find meaning of the information by themselves [15].

\section{CONCLUSION}

The implementation of the teachers training at the Training Institute of MORA in Palembang was in very good category. It means the committee and the trainers have worked hard to do the job based on their duty. However, the aspect of curriculum and syllabus of the training was not good according to the teachers. It should be the priority of the training institute to revise and improve its curriculum so that the updated issues on the teachers can always be accommodated. It is recommended for government to hold the best practice sharing 
among all madrasas in terms of these aspects. The improvement on the pedagogical of the teachers showed that the teachers got a lot of things from the training. However, there should be a follow up toward the training alumni, that made the instructors have access to the training outcomes so that the teachers keep their commitment to be professional on their duties. Another reccomendation was that the evaluation on the impacts should be held in the institutition in the provinces so the instructors had clues about the impacts of the training for the teachers. It is hoped that teachers training keep making contributions on the teachers quality for better quality education in madrasas as mandated by SDGs in Indonesia. By achieving quality education for all, it can be reaffirmed the belief that education is one of the most powerful and proven vehicles for sustainable development.

\section{REFERENCES}

[1] H. Hinzen and S. Schmitt, Agenda 2030 - Education and Lifelong Learning in the Sustainable Development Goals. Bonn: DVV International-International Perspectives in Adult Education, 2016.

[2] M. Maskur, "Eksistensi dan Esensi Pendidikan Madrasah di Indonesia," J. Pendidik. dan Pembelajaran Dasar, vol. 4, no. 1, 2017.

[3] M. Ali, J. Kos, P. Lietz, D. Nugroho, A. Zainul, and E. Emilia, Quality of Education in Madrasah. Washington: World Bank, 2011.

[4] A. Sjafrudin, "Pemanfaatan Hasil Ujian Nasional MA untuk Perbaikan Akses dan Mutu Pendidikan," Pendis Kemenag RI, 2008. [Online]. Available: http://pendis.kemenag.go.id/file/dokumen/PemanfaatanHasilUjianNasionalMAuntukP erbaikanMutuPendidikan.pdf.

[5] Komnasham, Kerangka Analisis untuk Mengintegrasikan Tujuan Pembangunan Berkelanjutan (SDGs) dengan Kewajiban Pemenuhan Hak-hak Asasi Manusia untuk di Indonesia. Jakarta: Komisi Nasional Hak Asasi Manusia, 2017.

[6] Kompas, "Kualitas Guru Madrasah Masih Rendah," Kompas, 2001. [Online]. Available: https://nasional.kompas.com/read/2008/03/17/20345773/Mutu.Madrasah.Masih.Renda h.

[7] J. L. Brendefur, K. Thiede, S. Strother, D. Jesse, and J. Sutton, "The Effects of Professional Development on Elementary Students' Mathematics Achievement," $J$. Curric. Teach., vol. 5, no. 2, 2016.

[8] K. F. Murtaza, "Teachers' Professional Development through Whole School Improvement Program (WSIP) Int.," J. Bus. Soc. Sci., vol. 1, no. 2, p. 213, 2010.

[9] R. P. H. and Y. Y. T. Bardwell A S, Fantuzzo J W, Stein S L, English D J, Gray E B, The Program Manager's Guide to Evaluation, 2nd ed. Washington: Department of Health and Human Services, Administration for Children and Families, Administration on Children, Youth, and Families, 2003.

[10] J. M. Werner and L. Randy, De Simone:Introduction to Human Resource Development. Mason: The Thomson Corporation, 2006.

[11] J. W. Creswell, Educational Research: Planning, Conducting, and Evaluating Quantitative and Qualitative Research. Boston: Pearson Education, Inc., 2012.

[12] M. G. F, D. Stufflebeam, and T. Kellaghan, Evaluation models. Boston: KluwerNijhoff, 2000.

[13] Ministry of Education and Culture, Peraturan Menteri Pendidikan Nasional No 16 tahun 2007 tentang Standar Kualifikasi Akademik dan Kompetensi Guru. Jakarta: 
Kemdikbud, 2007.

[14] S. Kant and B. Punia, "Perceptual Analysis of Training and Development Programmes: A Study of Academic Staff Colleges in India," Int. J. Soc. Sci. Humanit. Res., vol. 4, no. 5, pp. 535-542, 2016.

[15] Hamzah, Profesi Kependidikan, Problema, Solusi dan Reformasi Pendidikan. Jakarta: Bumi Aksara, 2007. 